\title{
11
}

\section{Environmental Conflict: Engaging with Scientific Information and Community Activism}

\author{
Jacki Schirmer
}

\section{Key Points}

- Land and water use planning often involves managing environmental conflict.

- Environmental conflicts are complex and can involve a wide range of substantive, procedural and psychological issues. They share one key characteristic: scientific evidence often plays a key role.

- Successful management of environmental conflict requires carefully considering how to ensure that scientific evidence is brought to bear in a way that supports dialogue, rather than deepening divisions and differences of view.

- This can be achieved by ensuring that agreement is reached between the parties involved in environmental conflict on the shared values that underpin the interpretation of scientific evidence, what is considered to be good-quality science (and the thresholds used to assess this) and how future 'unknowns' (in the form of new and emerging issues) will be dealt with to reduce the likelihood of conflict continuing to re-occur over time. 


\section{Box 11.1: Examples of the role of information in facilitating dialogue in environmental conflicts}

\begin{tabular}{|c|c|c|}
\hline $\begin{array}{l}\text { Environmental } \\
\text { conflict }\end{array}$ & Background & $\begin{array}{l}\text { How scientific information was } \\
\text { used to try to resolve this conflict }\end{array}$ \\
\hline $\begin{array}{l}\text { Regional } \\
\text { Forest } \\
\text { Agreements }\end{array}$ & $\begin{array}{l}\text { The RFA process was a response } \\
\text { to decades of conflict over the } \\
\text { harvesting of timber from native } \\
\text { forests in Australia. In several } \\
\text { regions across Australia, } \\
\text { multi-stakeholder groups were } \\
\text { convened from the mid-1990s } \\
\text { to the early 2000s to engage } \\
\text { in dialogue and agree on areas } \\
\text { of forest to be reserved and } \\
\text { those to be made available for } \\
\text { harvest into the future. The goal } \\
\text { was to sign RFAs between state } \\
\text { and federal governments that } \\
\text { guaranteed wood supply for } \\
20 \text { years, with the agreements } \\
\text { reviewed every five years. RFAs } \\
\text { were signed in most regions, } \\
\text { except for Queensland. However, } \\
\text { conflict over timber harvesting } \\
\text { has continued in most regions } \\
\text { since the RFAs were signed } \\
\text { (Musselwhite \& Herath, 2005). }\end{array}$ & $\begin{array}{l}\text { The RFAs included a strong } \\
\text { focus on gathering and assessing } \\
\text { scientific evidence to inform } \\
\text { discussions. A group of scientific } \\
\text { experts developed the 'JANIS } \\
\text { criteria' (JANIS, 1997)-a set } \\
\text { of standards for the reservation } \\
\text { of different forest types that } \\
\text { specified minimum proportions } \\
\text { of different forest types to be } \\
\text { placed in reserves, among } \\
\text { other things. However, critics } \\
\text { complained that the JANIS } \\
\text { criteria were 'watered-down' } \\
\text { by government representatives } \\
\text { after their initial formulation } \\
\text { (Kirkpatrick, 1998). A series } \\
\text { of Comprehensive Regional } \\
\text { Assessments were carried out to } \\
\text { collate existing information and, } \\
\text { in some cases, collect new data. } \\
\text { These data informed discussions } \\
\text { and decision-making. However, } \\
\text { the Comprehensive Regional } \\
\text { Assessment process, which } \\
\text { sometimes failed to integrate } \\
\text { different perspectives and values, } \\
\text { was criticised for being rushed } \\
\text { (Brueckner \& Horwitz, 2005). } \\
\text { While RFAs include a five-yearly } \\
\text { review process, which requires } \\
\text { monitoring of the implementation } \\
\text { of the RFA, there has not been } \\
\text { ongoing stakeholder dialogue } \\
\text { regarding the scientific evidence } \\
\text { for achieving desired RFA } \\
\text { outcomes. }\end{array}$ \\
\hline
\end{tabular}




\begin{tabular}{|c|c|c|}
\hline $\begin{array}{l}\text { Environmental } \\
\text { conflict }\end{array}$ & Background & $\begin{array}{l}\text { How scientific information was } \\
\text { used to try to resolve this conflict }\end{array}$ \\
\hline $\begin{array}{l}\text { Murray-Darling } \\
\text { Basin Plan }\end{array}$ & $\begin{array}{l}\text { The Murray-Darling Basin Plan } \\
\text { was a response to concerns } \\
\text { about the over-allocation of } \\
\text { water within the Murray-Darling } \\
\text { Basin, and a desire to provide } \\
\text { more sustainable irrigation water } \\
\text { supplies together with greater } \\
\text { water delivery to many important } \\
\text { wetland, river and nature areas } \\
\text { in the Basin. The plan was } \\
\text { developed by the Murray- } \\
\text { Darling Basin Authority (MDBA). } \\
\text { The development process } \\
\text { included initial consultations, } \\
\text { after which a guide to the } \\
\text { proposed plan was produced. } \\
\text { This was partly in response to } \\
\text { concerns about the relatively } \\
\text { centralised process of the } \\
\text { plan's development to that point } \\
\text { (Daniell, 2011). The guide, which } \\
\text { set out options for the plan, was } \\
\text { highly controversial; its release } \\
\text { was met with protests in several } \\
\text { irrigation-dependent communities } \\
\text { (Quiggin, 2012). The MDBA } \\
\text { subsequently engaged in further } \\
\text { consultation with a wide range } \\
\text { of groups before producing the } \\
\text { final plan, which was legislated } \\
\text { by the Australian Government in } \\
\text { November 2012. }\end{array}$ & $\begin{array}{l}\text { Multiple expert scientific } \\
\text { assessments were commissioned } \\
\text { by the MDBA to inform } \\
\text { development of the Murray- } \\
\text { Darling Basin Plan (Young, } \\
\text { Bond, Brookes, Gawne \& } \\
\text { Jones, 2011) and an advisory } \\
\text { committee was established to } \\
\text { provide expert advice on how } \\
\text { scientific knowledge should be } \\
\text { used in establishing the plan } \\
\text { (MDBA, 2014). However, many } \\
\text { stakeholder groups mistrusted } \\
\text { these assessments (Daniell, } \\
2011 \text {; MDBA, 2014). This led to } \\
\text { the commissioning of alternative } \\
\text { assessments by some stakeholder } \\
\text { groups-some of which offered } \\
\text { widely differing conclusions } \\
\text { (Regional Development Australia } \\
\text { Northern Inland, n.d.) and analyses } \\
\text { (e.g. Grafton \& Jiang, 2011). } \\
\text { The Murray-Darling Basin Plan } \\
\text { includes monitoring and evaluation } \\
\text { requirements over time; however, } \\
\text { the level of resourcing for the } \\
\text { assessment of scientific data as } \\
\text { part of these processes is unclear. }\end{array}$ \\
\hline
\end{tabular}




\begin{tabular}{|c|c|c|}
\hline $\begin{array}{l}\text { Environmental } \\
\text { conflict }\end{array}$ & Background & $\begin{array}{l}\text { How scientific information was } \\
\text { used to try to resolve this conflict }\end{array}$ \\
\hline $\begin{array}{l}\text { Tasmanian } \\
\text { forest peace } \\
\text { process }\end{array}$ & $\begin{array}{l}\text { The Tasmanian forest peace } \\
\text { process was a three-year } \\
\text { process of negotiations between } \\
\text { stakeholders involved in conflicts } \\
\text { over the harvesting of timber } \\
\text { from native forests in Tasmania. } \\
\text { Representatives from the forest } \\
\text { industry, environmental groups, } \\
\text { unions and community groups } \\
\text { met to try to agree on which } \\
\text { area of the native forest estate } \\
\text { in Tasmania currently available } \\
\text { for timber harvesting would be } \\
\text { placed in reserves. Government } \\
\text { representatives observed the } \\
\text { negotiation process in later } \\
\text { stages. The process resulted in } \\
\text { an agreement that was accepted } \\
\text { by the Tasmanian Government } \\
\text { and legislated as the Tasmanian } \\
\text { Forest Agreement (TFA) in April } \\
2013 \text {. However, after state } \\
\text { and federal elections returned } \\
\text { conservative governments, } \\
\text { the TFA was repealed in 2014 } \\
\text { (Schirmer, Dare \& Ercan, 2016). }\end{array}$ & $\begin{array}{l}\text { Scientific evidence was central } \\
\text { to the discussions. After a } \\
\text { year of negotiations in which } \\
\text { differences in interpretation of } \\
\text { available evidence by different } \\
\text { parties became apparent, a set } \\
\text { of principles for further steps to } \\
\text { achieve a peace agreement was } \\
\text { created. These steps included } \\
\text { a process for assessing the } \\
\text { available scientific evidence } \\
\text { to assist in answering key } \\
\text { questions that were central to } \\
\text { the negotiations; the questions } \\
\text { focused on the environmental } \\
\text { values of forests, sustainable } \\
\text { wood supplies and the socio- } \\
\text { economic effects of the changes } \\
\text { being proposed. An IVG was } \\
\text { established in 2011. This group } \\
\text { of experts was asked to assess } \\
\text { the evidence and report to the } \\
\text { negotiating parties in a relatively } \\
\text { short time frame (West, 2012). } \\
\text { Although not uncontested } \\
\text { (Poynter, 2013), the IVG's report } \\
\text { informed subsequent negotiations; } \\
\text { however, some felt it had limited } \\
\text { influence (Schirmer et al., 2016). }\end{array}$ \\
\hline
\end{tabular}

\section{Introduction}

Land use planning in Australia often involves the management of environmental conflict: disagreements over how best to manage Australia's land and water resources are common and have been for many years (Mercer, 2000). Environmental conflicts are diverse, ranging from disputes about local land use developments, such as new wind farms or intensive livestock farming operations, to large-scale protests and concerns about issues such as the harvesting of timber from native forests, coal seam gas extraction or water allocation in the Murray-Darling Basin, to provide just a few examples.

Like any form of social conflict, environmental conflict is driven by many factors, including substantive, procedural and psychological interests. Substantive issues focus on the claims of fact being made, such as differing 
views about the environmental impacts of a particular land use. Procedural issues focus on the processes by which people raise concerns and engage in dialogue about environmental issues. Psychological interests refer to the relationships between people involved in the conflict-they have an important effect on the likelihood of successfully addressing the conflict (Furlong, 2010). Scientific information and evidence plays an important role in environmental conflict. It is frequently utilised by parties engaged on different sides of a conflict to support their points of view or provide 'definitive' answers. This sometimes results in 'science wars', in which different parties put forward differing claims about the scientific evidence for an environmental issue (Harding, Hendriks \& Faruqi, 2009; Schirmer, 2013; Wynne, 2006).

Scientific evidence has much asked of it in environmental conflicts; the hope that it can be used to resolve conflicts by providing unbiased, independent evidence is often misplaced. Scientific evidence, like any form of social knowledge, reflects the conscious and unconscious values and positions held by those who produce it and interpret its meaning. Frequently funded by those with particular points of view, the scientific evidence produced for environmental conflicts may focus on answering questions that are constructed in ways that favour one side or another, and may be interpreted in different ways depending on values and points of view. Consequently, scientific data can as readily exacerbate conflict as resolve it (Schirmer, 2013).

Yet, despite these challenges, scientific evidence has a critical role to play in environmental conflicts. The solution to the problems that arise when attempting to draw on this evidence is not to attempt to reach 'valuefree' science; instead, those involved in dialogue about environmental issues should actively discuss and agree upon the values and perspectives underpinning the collection and interpretation of scientific data (Longino, 1990). Scientific evidence can only contribute constructively to environmental conflict resolution if careful attention is paid to how, when and why the evidence was collected, used and interpreted.

How, then, can scientific data be used constructively, rather than destructively, to help address environmental conflict in Australia? This chapter proposes three principles, based on modern conflict resolution theory, for the constructive use of scientific data: agreeing on values, agreeing on how to 'do the science' and agreeing on how to deal with the 'unknowns'. These are examined in the context of a review of the scientific 
data used in attempts to resolve three prominent Australian environmental conflicts: Regional Forest Agreements (RFAs), the Murray-Darling Basin Plan and the Tasmanian forest peace process (see Box 11.1).

\section{Principle 1: Agree on Your Values}

Science is not value free. Ideally, the values that underpin the interpretation of scientific evidence should be agreed upon by the different groups involved in a conflict prior to assessment of the scientific evidence. Enabling agreement to be reached on shared values and interpretation techniques will help to ensure that scientific evidence supports productive dialogue, rather than further enhancing disagreement between stakeholders.

To some extent, the RFA process achieved this by implementing a set of criteria-known as the 'JANIS criteria'-that specified the proportion of forests of different types that should be reserved to create a comprehensive, adequate and representative reserve system. The criteria were agreed upon by the various parties involved in the negotiations. While the final JANIS criteria were criticised by some scientists and environmental groups, they were nevertheless useful, as they provided a set of values to guide decision-making based on the scientific evidence examined in the RFA negotiations. In the Tasmanian forest peace process, stakeholders reached early agreement on the principles by which their negotiations would proceed, including, for example, agreement that the negotiating parties would seek to support a sustainable native forest industry; later, this assisted in the use and interpretation of scientific data. By contrast, in the Murray-Darling Basin Plan process, there was no agreement on values between stakeholders. When there was protest regarding the extent to which socio-economic effects should be considered in determining sustainable levels of water diversion in the Basin, this lack of agreement on values exacerbated the conflict.

It is not easy to create space to discuss values prior to assessing scientific evidence in environmental conflicts; however, doing so can assist in building consensus on the interpretation of available scientific evidence. The key areas to be discussed are the subjective values and thresholds to be applied when making decisions based on science, such as the area of a representative ecotype that should be preserved, or the weight to be given to social and economic effects versus ecological outcomes of a land use decision. 


\section{Principle 2: Agree How You Will Do the Science}

Scientific evidence is only effective if all stakeholders trust the way the evidence was collected, the people who collected the evidence and the way data have been interpreted. In an ideal world, these things would be agreed upon prior to the collection of scientific data. In reality, it is usually not possible to collect large volumes of new scientific evidence to inform stakeholder discussions in environmental conflicts. Instead, existing scientific evidence must be relied upon - that is, evidence collected for a wide range of purposes by a wide range of researchers. Agreeing how to interpret this evidence and assess its validity and reliability is an essential first step to enabling constructive use of scientific evidence as part of dialogue. Ensuring that people with different viewpoints and perspectives are involved in reaching this agreement contributes to improved procedural justice, which in turn assists in achieving constructive dialogue between parties. Agreeing on the principles by which the quality, comprehensiveness and adequacy of scientific evidence will be evaluated assists in addressing substantive issues of the conflict, as it reduces the likelihood that the same evidence will be interpreted differently by different parties. Therefore, ensuring a shared approach to understanding the science of the conflict enables better utilisation of scientific evidence to address the substantive issues at the heart of many environmental conflicts.

This process of agreement on how scientific evidence will be used, interpreted and understood prior to its evaluation is not commonly undertaken, and the extent to which it occurred in the three conflicts examined in this chapter is not always clear. In the RFAs and the MurrayDarling Basin Plan, a lack of agreement on the meaning and interpretation of the available science was apparent both before and after attempts at negotiating the conflicts. The Tasmanian peace process was somewhat different. All the negotiating parties explicitly agreed to the appointment of the experts who assessed the available scientific evidence- that is, the chosen experts were trusted in theory by all parties to assess and interpret available data. In addition, the negotiating parties explicitly agreed on the type of data to be evaluated and the questions to be answered in the evaluation of data. This agreement on the parameters of the assessment helped to ensure that the scientific evidence produced by the experts appointed to the Independent Verification Group (IVG) was accepted by the negotiating parties. Disagreements about areas of evidence occurred 
less frequently after the IVG assessment. This suggests that gaining explicit agreement on the assessors and areas to be assessed, while having limitations (Schirmer, Dare \& Ercan, 2016), assisted in enabling the evidence to be used constructively in subsequent negotiations, rather than becoming another area of disagreement among participants.

\section{Principle 3: Agree How to Deal with Unknowns}

Scientific understandings of environmental systems are constantly evolving. Scientific evidence and knowledge that is current at a given point in time will almost inevitably be superseded as land and water use changes, and as scientific knowledge evolves. Attempts to resolve environmental conflicts at a given point in time are unlikely to succeed unless a mechanism is included for monitoring and evaluating outcomes, and for reviewing what has been agreed to as new evidence emerges; this means including a process for how to address 'unknowns' - that is, factors that will likely emerge in the future — as part of any agreement reached about an environmental conflict.

The RFAs dealt with this by requiring forest management systems to be 'capable of responding to new information' (Commonwealth of Australia and State of Tasmania, 1997), and by having a five-yearly review that evaluated whether the systems were meeting the requirements of the RFA (including responding to new information). The Murray-Darling Basin Plan has similar requirements for monitoring and evaluation. However, in both these processes, there is limited ongoing funding for evaluating emerging scientific evidence, which is likely to limit the effectiveness of these review and monitoring processes in addressing new and emerging issues. This is a key issue, for when new concerns and evidence emerge, fresh conflict will almost inevitably arise unless there is a transparent process available by which these can be evaluated or addressed-in other words, a space in which stakeholders can raise and discuss issues that were unknown when the original agreement was reached. 


\section{Recommendations}

Successfully managing land use in Australia requires robust systems for addressing environmental conflict in constructive and appropriate ways. A critical part of this is ensuring that scientific evidence contributes to achieving greater consensus, rather than further deepening and dividing opinions about how best to manage Australia's diverse environments. The following three principles can assist in doing this:

- Agree on your values: How will the science be interpreted? What values will be used to determine thresholds of acceptable social, economic and environmental impacts of land use change? Agreement on shared values reduces the potential for scientific evidence to be interpreted differently by different groups.

- Agree on how you will do the science: Explicitly agree on who will evaluate scientific evidence. Which scientific experts are accepted by all those involved in an environmental conflict? What criteria will be used to judge the quality, validity and reliability of scientific evidence?

- Agree on how to deal with unknowns: How will emerging and new evidence be identified, examined and responded to into the future?

Successfully implementing these principles requires constructive dialogue between all parties involved in the conflict. They will not assist in the interpretation of scientific evidence if some parties' views have not been included in the discussion of, and agreement on, the principles. Their success rests on ensuring that those involved in a conflict have the time and resources to discuss issues and agree on principles. Successfully bringing scientific evidence to bear in environmental conflicts requires constructive and inclusive dialogue between all parties.

\section{References}

Brueckner, M. \& Horowitz, P. (2005). The use of science in environmental policy: A case study of the regional forest agreement process in Western Australia. Sustainability: Science, Practice, \& Policy 1(2), 14-24.

Commonwealth of Australia and State of Tasmania. (1997). Tasmanian regional forest agreement. Canberra, ACT: Commonwealth of Australia. 
Daniell, K. A. (2011). Enhancing collaborative management in the basin. In D. Connell \& Q. Grafton (Eds.), Basin Futures: Water reform in the Murray-Darling Basin (pp. 413-37). Canberra, ACT: ANU E Press.

Furlong, G. T. (2010). The conflict resolution toolbox: Models and maps for analyzing, diagnosing, and resolving conflict. Hoboken, NJ: John Wiley $\&$ Sons.

Grafton, Q. R. \& Jiang, Q. (2011). Economic effects of water recovery on irrigated agriculture in the Murray-Darling Basin, Australian Journal of Agricultural and Resource Economics 55(4), 487-99. doi.org/ 10.1111/j.1467-8489.2011.00545.x

Harding, R., Hendriks, C. M. \& Faruqi, M. (2009). Environmental decision-making: Exploring complexity and context. Sydney, NSW: Federation Press.

JANIS (Joint ANZECC/MCFFA National Forest Policy Statement Implementation Sub-committee). (1997). Nationally agreed criteria for the establishment of a comprehensive, adequate and representative reserve system for forests in Australia. Canberra, ACT: Australian Government Publishing Service.

Kirkpatrick, J. B. (1998). Nature conservation and the Regional Forest Agreement process. Australian Journal of Environmental Management 5(1), 31-7. doi.org/10.1080/14486563.1998.10648397

Longino, H. E. (1990). Science as social knowledge: Values and objectivity in scientific inquiry. Princeton, NJ: Princeton University Press.

Mercer, D. (2000). A question of balance: Natural resources conflict issues in Australia. Sydney, NSW: Federation Press.

MDBA (Murray-Darling Basin Authority). (2014). The journey to a basin plan-an overview. Canberra, ACT: Murray-Darling Basin Authority.

Musselwhite, G. \& Herath, G. (2005). Australia's regional forest agreement process: Analysis of the potential and problems. Forest policy and Economics 7(4), 579-88. doi.org/10.1016/j.forpol.2003.11.001

Poynter, M. (2013). Response to Martin Moroni's guest editorial in Australian forestry. Australian Forestry 76(1), 69-70. doi.org/10.1080/ 00049158.2013.776929 
Quiggin, J. (2012). Why the guide to the proposed basin plan failed, and what can be done to fix it. In J. Quiggin, S. Chambers \& T. Mallawaarachchi (Eds.), Water policy reform lessons in sustainability from the Murray-Darling Basin (pp. 49-60). Cheltenham, UK: Edward Elgar. doi.org/10.4337/9781781000328.00014

Regional Development Australia Northern Inland. (n.d.). Measuring the socio-economic impacts of the MDB Plan. Retrieved from www.rdani. org.au/our-region/current-regional-issues/socioeconomic-impacts-ofthe-murray-darling-basin-plan.php

Schirmer, J. (2013). Engaging with scientific data: Making it meaningful. In H. J. Aslin \& S. Lockie (Eds.), Engaged environmental citizenship (pp. 87-105). Darwin, NT: Charles Darwin University Press.

Schirmer, J., Dare, L. \& Ercan, S. (2016). Deliberative democracy and the Tasmanian forest peace process. Australian Journal of Political Science 51(2), 288-307. doi.org/10.1080/10361146.2015.1123673

West, J. (2012). Final report on the work of the independent verification group for the Tasmanian forests Intergovernmental agreement. Retrieved from www.environment.gov.au/resource/independent-verification-groupreport

Wynne, B. (2006). Public engagement as a means of restoring public trust in science-hitting the notes, but missing the music? Community Genetics 9, 211-20. doi.org/10.1159/000092659

Young, W. J., Bond, N., Brookes, J., Gawne, B. \& Jones, G. J. (2011). Science review of the estimation of an environmentally sustainable level of take for the Murray-Darling Basin. Retrieved from www.mdba. gov.au/sites/default/files/archived/proposed/CSIRO_ESLT_Science_ Review.pdf 
This text is taken from Land Use in Australia: Past, Present and Future, edited by Richard Thackway, published 2018 by ANU eView, The Australian National University, Canberra, Australia.

doi.org/10.22459/LUA.02.2018.11 